Endocrinol. Japon. 1987, 34 (1), 105-115

\title{
Ketoconazole as a Possible Universal Inhibitor of Cytochrome P-450 Dependent Enzymes : Its Mode of Inhibition ${ }^{1}$
}

\author{
Yotsuo HIGASHI ${ }^{2}$, Masako OMURA, Keiko SUZUKI*, Hiroshi INANO* \\ AND HIROYUKI OSHIMA
}

\author{
Department of Urology, Tokyo Medical and Dental University School of \\ Medicine, Bunkyo-ku, Tokyo 113 and National Institute of \\ Radiological Sciences, Chiba 260*, Japan
}

\begin{abstract}
Modes of inhibition and binding of ketoconazole, an orally antimycotic agent, to NADPH-cytochrome P-450 dependent enzymes were investigated using subcellular fractions of human and rat testes, human adrenocortical adenoma tissue and rat adrenals and livers. Ketoconazole competitively inhibited the activities of steroid $17 \alpha$-hydroxylase and C17-20 lyase in rat and human testes, $16 \alpha$-hydroxylase in human testes and 21-hydroxylase in rat adrenal glands. $\mathrm{Ki}$ values were in the order of $10^{-8} \mathrm{M}$ for human testicular enzymes, while the order was $10^{-7}-10^{-6} \mathrm{M}$ for rat adrenal and testicular enzymes. Kinetic studies indicated that ketoconazole bound to cytochrome P-450 and not to other components of monooxygenase systems. Spectrophotometric studies also revealed direct binding of ketoconazole to cytochrome P-450 component by inducing type II difference spectra in all tissue preparations examined, indicating that ketoconazole is possibly a universal inhibitor of NADPH-cytochrome P-450 dependent monooxygenases which are involved in metabolism of many substances including steroids, toxins, carcinogens and others.
\end{abstract}

An imidazole agent, ketoconazole (cis1-acetyl-4-\{4-[[2-(2, 4-dichlorophenyl)-2-(1Himidazol-1-ylmethyl)-1, 3-dioxalan-4-yl]methoxy]phenyl piperazine) is an orally active broad-spectrum antifungal drug. It inhibits production of ergosterol in yeast cell by blocking the $14 \alpha$-demethylation of lanosterol (Van den Bossche et al., 1980). However,

\section{Received September 12, 1986}

1. This work is supported in part by Grant-inAid No. 61010012 for Cancer Research from the Ministry of Education, Science and Culture of Japan.

2. To whom requests for reprints should be addressed. gynecomastia, impotence or adrenal insufficiency has occurred during clinical use of this agent (De Felice et al., 1981; Tucker et al., 1985), as a result of interference of steroid biosynthesis in both testes and adrenal glands (Pont et al., 1982 a, b; Shurmeyer and Nieschlag, 1982). Steroid synthetic reactions documented to be inhibited by the agent are $17 \alpha$-hydroxylation and side chain cleavage at $\mathrm{C} 17-20$ in the rat testis (Sikka et al., 1985) and side chain cleavage of cholesterol and $11 \beta$-hydroxylation of deoxycorticosterone in the adrenal gland (Loose et al., 1983; Kowal, 1983). These reactions are catalyzed by cytochrome 
P-450 dependent monooxygenases, and in fact, the binding of an imidazole agent, miconazole (1-[2, 4-Dichloro- $\beta$ - $](2,4$-dichlorobenzyl)oxy]phenethyl]imidazole) to cytochrome P-450 component of human placental microsome aromatizing enzyme has been proved by a spectrophotometric study (Mason et al., 1983).

These data suggest that ketoconazole is a universal inhibitor of cytochrome P-450 dependent monooxygenases which catalyze hydroxylation of many compounds in the process of biosynthesis and catabolism. Up to the present, however, the mechanism of inhibition by ketoconazole has not been well elucidated. Therefore, the present study was designed to clarify the inhibition mode and binding site of ketoconazole to the NADPHcytochrome P-450 monooxygenase system using human and rat tissues.

\section{Materials and Methods}

\section{Chemicals}

$\left[4-{ }^{14} \mathrm{C}\right]$ Progesterone (SA, $\left.57 \mathrm{Ci} / \mathrm{mmol}\right),\left[4-{ }^{14} \mathrm{C}\right]-$ $17 \alpha$-hydroxy-progesterone (SA, $50 \mathrm{Ci} / \mathrm{mmol}$ ) and Econofluor were purchased from New England Nuclear Corp. (Boston, MA). Non-radioactive steroids and NADPH were products of Sigma Chemical Co. (St. Louis, MO). Ketoconazole was supplied by Kyowa Hakko Co. (Tokyo, Japan). Emulgen 913 was a gift from Kao-Atlas Co. (Tokyo, Japan). All other reagents were of analytical grade and all organic solvents were redistilled.

\section{Tissue preparations}

Human testicular tissue: Testicular tissue was obtained from patients at orchiectomy as the treatment of prostatic carcinoma. None had received any prior hormonal treatment.

The removed tissue was immediately frozen in liquid nitrogen and stored at $-70^{\circ} \mathrm{C}$ until use. The frozen tissue was allowed to thaw at $4^{\circ} \mathrm{C}$, and then homogenized with an Ultra-Turrax homogenizer (Ika-Werk Co., West Germany) in 5 volumes of $0.25 \mathrm{M}$ sucrose solution ( $\mathrm{pH}$ 7.4).

The mitochondrial and microsome fractions were prepared by conventional differential centrifugation at $800-10,000 \times \mathrm{g}$ for $20 \mathrm{~min}$. and $10,000-105,000 \times \mathrm{g}$ for $60 \mathrm{~min}$., respectively (Shikita and Tamaoki, 1965). The precipitates were resuspended in fresh ice cold $0.25 \mathrm{M}$ sucrose solution and recentrifuged as above to obtain washed mitochondrial and microsome fractions. All procedures were performed at $0-4^{\circ} \mathrm{C}$.

Human adrenal gland: Adrenal tissue was obtained at adrenalectomy of a patient with adrenal adenoma manifesting Cushing's syndrome. The removed adrenal adenoma was immediately frozen and stored at $-70^{\circ} \mathrm{C}$ until use. The frozen tissue was homogenized with an UltraTurrax homogenizer in approximately 5 volumes of $0.33 \mathrm{M}$ sucrose solution ( $\mathrm{pH} 7.4)$. The mitochondrial and microsome fractions were prepared by differential centrifugation as described above.

Rat liver, adrenal gland and testis: Adult male Wistar rats, aged 12 weeks with a body weight of $250-280 \mathrm{~g}$ were sacrificed by decapitation. Livers, adrenal glands and testes were immediately removed and homogenized with an Ultra-Turrax homogenizer in approximately 4 volumes of $0.13 \mathrm{M}$ potassium-phosphate buffer ( $\mathrm{pH}$ 7.4), 10 volumes of $0.33 \mathrm{M}$ sucrose $(\mathrm{pH} 7.4)$ and 4 volumes of $0.25 \mathrm{M}$ sucrose ( $\mathrm{pH} 7.4)$ solutions, respectively. Mitochondrial and microsome fractions were prepared from each homogenate by differential centrifugation.

Verification of tissue preparations: Isocitrate dehydrogenase (E. C. 1.1.1.42) (Nordlie and Arion, 1966) and glucose-6-phosphate phosphohydrolase (E. C. 3.1.3.9) (Bachmann et al., 1966) were measured as a marker enzyme of the mitochondrial and microsome fractions, respectively, to verify the purity of the tissue preparations.

Assay of enzymes related to steroid biosynthesis

Incubations: All incubations were carried out in duplicate. The incubation medium contained the microsome fraction, one of ${ }^{14} \mathrm{C}$-labeled steroid substrates, $0.25 \mathrm{M}$ sucrose, $17 \mathrm{mM}$ Tris ( $\mathrm{pH} 7.4), 1.7 \mathrm{mM} \mathrm{MgCl} 2$ and $0.2 \mathrm{mM} \mathrm{NADPH}$ in the presence or absence of ketoconazole. The concentration of steroid substrates and ketoconazole is indicated in the legends to figures. The final volume of incubation medium was $3 \mathrm{ml}$. The specific radioactivity of each steroid sub- 
strate was adjusted with corresponding authentic non-radioactive steroids to obtain the desired substrate concentrations. Incubations were carried out at $37^{\circ} \mathrm{C}$ for $20 \mathrm{~min}$. under an atmosphere of $95 \% \mathrm{O}_{2}$ and $5 \% \mathrm{CO}_{2}(\mathrm{v} / \mathrm{v})$. The enzyme reaction was started by adding the microsome fraction and terminated by vigorous shaking of the incubation flask after additing $10 \mathrm{ml}$ methylene dichloride.

Extraction, separation and identification of steroids: After adding non-radioactive carrier steroids (100 $\mu \mathrm{g}$, each), extraction was repeated three times with $10 \mathrm{ml}$ methylene dichloride. The combined extracts were dried over anhydrous sodium sulfate and concentrated at $40^{\circ} \mathrm{C}$ under reduced pressure. The residue was applied to ascending thin layer chromatography of silica gel $\mathrm{G}$ and GF $254(4: 1, \mathrm{w} / \mathrm{w})$ with the benzene and acetone solvent system $(4: 1, \mathrm{v} / \mathrm{v})$. Carrier and radioactive steroids on the thin layer plate were each detected under UV light $(254 \mu \mathrm{m})$ and autoradiography, and exhaustively eluted from silica gel with a mixture of chloroform and ethanol $(1: 1, \mathrm{v} / \mathrm{v}) . \quad 16 \alpha$-Hydroxyprogesterone was identified by chromatographic mobilities combined with chemical derivative formations (Oshima et al., 1967).

Identification of other metabolites was accomplished by demonstrating constant specific radioactivities during repeated recrystallization with corresponding authentic steroid preparations (Higashi et al., 1984). Once identification and purity of the products were established as above the metabolites obtained in subsequent experiments under similar conditions were identified using a combined method of derivative formation and chromatographic mobilities.

Expression of enzyme activities: Enzyme activities were expressed as the sum of metabolites produced by the enzyme action on the substrate. When progesterone was used as a substrate, the metabolites detected on the autoradiogram were $16 \alpha$-hydroxy-progesterone, $17 \alpha$ hydroxyprogesterone and 20 $\alpha$-hydroxy-4-pregnen3-one. The radioactivities in fractions which coincided with androstenedione and testosterone on the thin layer plate were examined but were too limited for quantitation. Therefore, activities of $16 \alpha$-hydroxylase (steroid, hydrogen donor: oxygen oxydoreductase (16 $\alpha$-hydroxylating)) and $17 \alpha$-hydroxylase (E. C. 1.14.99.9) were expressed as the amount of $16 \alpha$-hydroxyprogesterone and the amount of $17 \alpha$-hydroxyprogesterone produced from progesterone, respectively. The sum of androstenedione and testosterone produced from $17 \alpha$-hydroxyprogesterone indicated the activity of C17-20 lyase (E. C. 4.1.2.30) for 17 $\alpha$-hydroxyprogesterone. Since deoxycorticosterone was the only detectable metabolite produced from progesterone in rat adrenal microsome fraction, its amount was employed as the activity of 21hydroxylase (E. C. 1.14.99.10).

Enzyme activities expressed as above showed linear relationships with either incubation time up to $30 \mathrm{~min}$. or the amounts of tissue preparations added under the conditions employed in the present study.

\section{Quantitation of steroids and protein}

The radioactivity of each steroid fraction was measured with a liquid scintillation spectrometer (Packard, TRI-CARB 460) in the scintillation cocktail Econofluor. The amount of each metabolite was calculated from its percent yield and the specific radioactivity of the substrate. Over $90 \%$ of the initial radioactivity was recovered.

The protein content in each tissue preparation was determined by the methods of Lowry et al. (1951).

Analysis of CO-binding and substrate-induced difference spectra of cytochrome P-450

CO-binding spectrum of mitochondrial cytochrome P-450 of rat adrenal gland was obtained by the modified method of Omura et al. (1964). Briefly, mitochondrial fraction suspended in 6 $\mathrm{ml}$ of $100 \mathrm{mM}$ potassium-phosphate buffer $(\mathrm{pH}$ 7.25) containing $0.07 \%$ Emulgen 913 was prepared and after additing a few mg sodium dithionite, the mixture was divided and put into sample and reference cuvettes. The $\mathrm{CO}$ gas was slowly bubbled in the sample cuvette for $1 \mathrm{~min}$. The difference spectrum of cytochrome P-450 was obtained with a spectrophotometer (Hitachi 20020, Japan) with cuvettes having a $1 \mathrm{~cm}$ optical path.

Substrate-induced difference spectra of cytochrome P-450 were analyzed using mitochondrial and microsome fractions. Each tissue preparation was adjusted to $6 \mathrm{ml}$ with $100 \mathrm{mM}$ potassiumphosphate buffer containing $0.07 \%$ Emulgen 913 . The suspension was divided into two equal portion and poured into cuvettes. The sample cuvette was titrated with an ethanol solution of various concentrations of ketoconazole as a sub- 
strate, and the corresponding volume of ethanol was added to the reference cuvette. The final concentration of ethanol was less than $2.5 \%$. The difference spectra were measured from 350 to $500 \mathrm{~nm}$ (Suzuki and Tamaoki, 1983). Other conditions were described in legends to figures.

Effect of ketoconazole on NADPH-cytochrome $c$ $(P-450)$ reductase activity

Purification of NADPH-cytochrome $c$ (P-450) reductase (E. C. 1.6.2.4) from rat liver and testes and measurement of the activity was carried out according to the method of Omura and Takesue (1970) with slight modifications. The reaction mixture in the microcuvette contained $20 \mathrm{nmol}$ horse heart cytochrome $c$ and $100 \mathrm{nmol}$ NADPH in $1 \mathrm{ml}$ of $100 \mathrm{mM}$ phosphate buffer ( $\mathrm{pH} 7.4)$. The enzyme reaction was initiated by adding purified NADPH-cytochrome $c$ reductase. The spectrum obtained by the reduction of cytochrome $c$ was followed at $550 \mathrm{~nm}$ for $3 \mathrm{~min}$. at ambient temperature. To determine the effect of ketoconazole, the spectrum was measured in the same manner in the presence of $85 \mu \mathrm{M}$ ketoconazole.

\section{Results}

Effect of ketoconazole on enzyme activities of the human testicular microsome cytochrome $P-450$ dependent monooxygenases

As shown in Fig. 1, ketoconazole dosedependently inhibited cytochrome P-450 dependent monooxygenases including $\mathrm{C} 17-20$ lyase for $17 \alpha$-hydroxyprogesterone, $16 \alpha$ - and $17 \alpha$-hydroxylases for progesterone.

Fig. 2 shows the mode of inhibition by ketoconazole of C17-20 lyase, 16 $\alpha$ - and $17 \alpha$-hydroxylases with the Lineweaver-Burk plot. As shown in Table 1, the inhibition was competitive to all of enzymes examined and $\mathrm{Ki}$ values ranged from approximately one twentieth to one sixtieth of the corresponding $\mathrm{Kms}$, indicating high affinity of ketoconazole with human testicular monooxygenases.

Mode of inhibition of microsome monooxygenases in rat testes and adrenal gland by ketoconazole

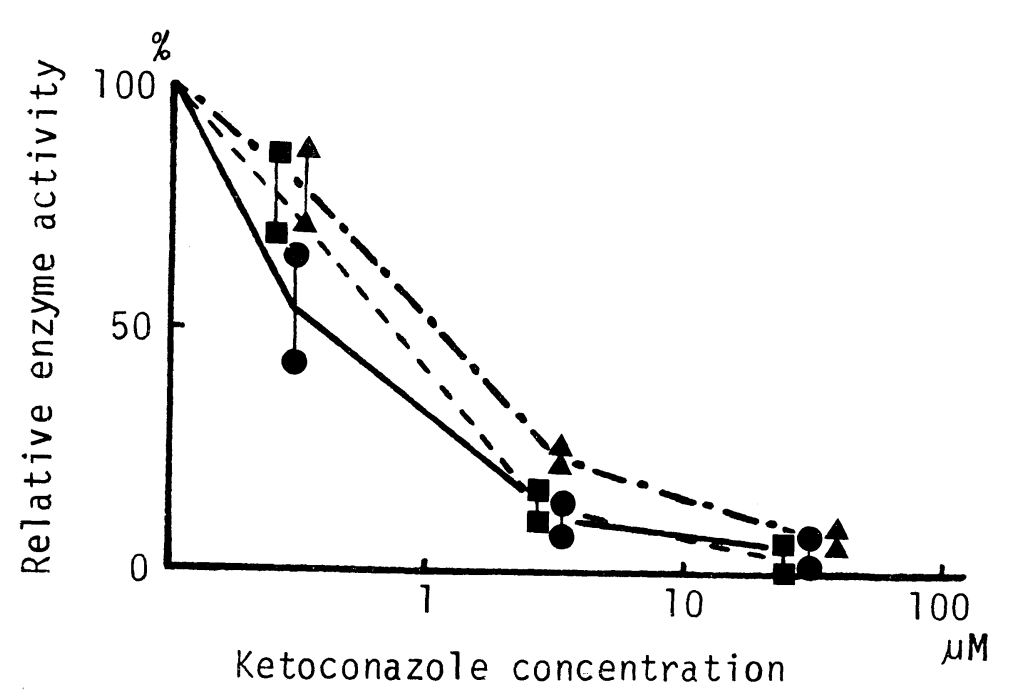

Fig. 1. Dose-related inhibition of activities of cytochrome P-450 dependent monooxygenases in human testicular microsome fractions by ketoconazole.

Microsome fractions were incubated with 10.6 $\mu \mathrm{M}$ progesterone or 5.0 $\mu \mathrm{M} 17 \alpha$-hydroxyprogesterone in the presences of $0,0.31,3.1$ or $31.3 \mu \mathrm{M}$ ketoconazole. Two separate duplicated experiments were carried out using different tissues obtained from patients with prostatic cancer. Symbols show the mean for each duplicate experiment. Microsome fractions contained 10.8 $\mathrm{mg}$ protein/flask in one and $9.8 \mathrm{mg}$ protein/flask in the other.

; C17-20 lyase for $17 \alpha$-hydroxyprogesterone, $\boldsymbol{\Delta} ; 17 \alpha$-hydroxylase for progesterone and $\square$; $16 \alpha$-hydroxylase for progesterone. 

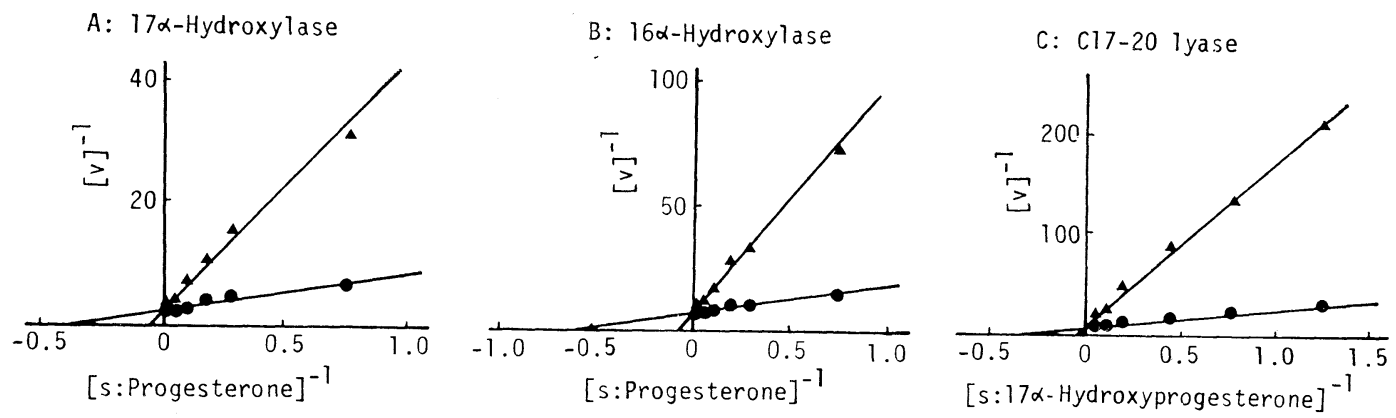

Fig. 2. Mode of inhibition of cytochrome P-450 dependent monooxygenases in the human testis by ketoconazole.

Microsome fractions containing $4.5 \mathrm{mg}$ protein/flask for $\mathrm{A}$ and $\mathrm{B}$, and $5.6 \mathrm{mg}$ protein/flask for $\mathrm{C}$ were incubated in the absence $(\mathbf{O})$ or presence $(\mathbf{\Delta})$ of ketoconazole. Ketoconazole concentrations were $0.63 \mu \mathrm{M}$ for $\mathrm{A}$ and $\mathrm{B}$, and $0.31 \mu \mathrm{M}$ for $\mathrm{C}$. $\mathrm{v}$; amount of product in $\mathrm{nmol} / \mathrm{mg}$ protein $/ 20 \mathrm{~min}$. and $\mathrm{s}$; substrate concentration in $\mu \mathrm{M}$.

Table 1. Mode of inhibition by ketoconazole of microsome monooxygenases in human testis.

\begin{tabular}{clccc}
\hline \multirow{2}{*}{ Enzyme } & \multirow{2}{*}{ Substrate } & \multirow{2}{*}{$\begin{array}{c}\text { Km } \\
(\mu \mathrm{M})\end{array}$} & \multicolumn{2}{c}{ Inhibition by ketoconazole } \\
\cline { 5 - 5 } & & $\mathrm{Ki}(\mu \mathrm{M})$ & type \\
\hline $17 \alpha$-hydroxylase & progesterone & 2.5 & 0.09 & competitive \\
16 $\alpha$-hydroxylase & progesterone & 1.5 & 0.08 & competitive \\
C17-20 lyase & $\begin{array}{l}17 \alpha \text {-hydroxy- } \\
\text { progesterone }\end{array}$ & 2.5 & 0.04 & competitive \\
\hline
\end{tabular}

Values are calculated from Fig. 2

Enzymes in microsome fractions of rat adrenal glands and testes were also studied under similar conditions. As shown in Fig. 3, the Lineweaver-Burk plot of the kinetic study revealed competitive inhibition by ketoconazole of $17 \alpha$-hydroxylase for progesterone and $\mathrm{C} 17-20$ lyase for 17 $\alpha$-hydroxyprogesterone in rat testes, and 21-hydroxylase for progesterone in rat adrenal glands. The $\mathrm{Ki}$ value of ketoconazole for each enzyme was determined and shown in Table 2 , and found rather higher than those for human testicular ones, indicating the different affinities of ketoconazole with rat and human cytochrome P-450 dependent monooxygenases.

Effect of ketoconazole on 17 $\alpha$-hydroxylase for NADPH and NADPH-cytochrome $c(P-450)$ reductase activity
Ketoconazole was a non-competitive inhibitor of $17 \alpha$-hydroxylase for NADPH as demonstrated in Fig. 4.

To evaluate the interaction between ketoconazole and NADPH-cytochrome $c$ (P450) reductase, activities of NADPH-cytochrome $c$ reductase purified from rat liver and testes were examined by the spectral method. The results indicated that NADPHcytochrome $c$ reductase activity was not influenced by ketoconazole at the concentration examined $(85 \mu \mathrm{M})$, although the concentration was sufficient to inhibit the microsome cytochrome P-450 dependent monooxygenases, i.e. C17-20 lyase, $16 \alpha$ - and $17 \alpha$ hydroxylases.

Mode of ketoconazole and deoxycorticosterone binding to rat mitochondrial cytochrome P-450 A typical CO-binding spectrum of reduced 
A: Testis $17 \alpha$-hydroxylase

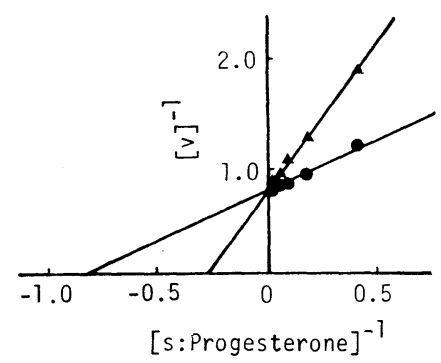

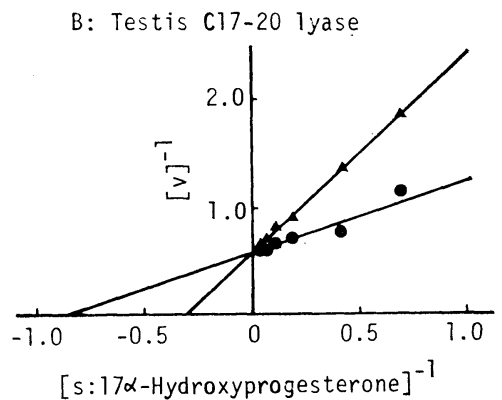

C: Adrenal 21-hydroxylase

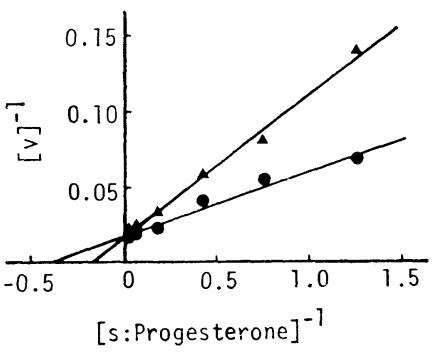

Fig. 3. Mode of inhibition by ketoconazole of cytochrome P-450 dependent monooxygenases in rat testes and adrenal glands.

Microsome fractions containing $3.4 \mathrm{mg}$ protein/flask for A and B, and $0.07 \mathrm{mg}$ protein/flask for $\mathrm{C}$ were incubated in the absence $(\mathbf{O})$ or presence $(\boldsymbol{A})$ of ketoconazole. Ketoconazole concentrations were $3.1 \mu \mathrm{M}$ for $\mathrm{A}$, and $0.63 \mu \mathrm{M}$ for $\mathrm{B}$ and $\mathrm{C}$.

Table 2. Mode of inhibition by ketoconazole of microsome monooxygenases in rat testes and adrenal gland.

\begin{tabular}{cccccc}
\hline \hline Enzyme & (Organ) & Substrate & $\begin{array}{c}\mathrm{Km} \\
(\mu \mathrm{M})\end{array}$ & \multicolumn{2}{c}{ Inhibition by ketoconazole } \\
\hline $17 \alpha$-hydroxylase & & progesterone & 1.2 & 1.6 & type \\
C17-20 lyase & (Testis) & $\begin{array}{l}17 \alpha \text {-hydroxy- } \\
\text { progesterone }\end{array}$ & 1.4 & 0.4 & competitive \\
21-hydroxylase & $\begin{array}{l}\text { (Testis) } \\
\text { progesterone }\end{array}$ & 2.5 & 5.0 & competitive \\
\hline
\end{tabular}

Values are calculated from Fig. 3

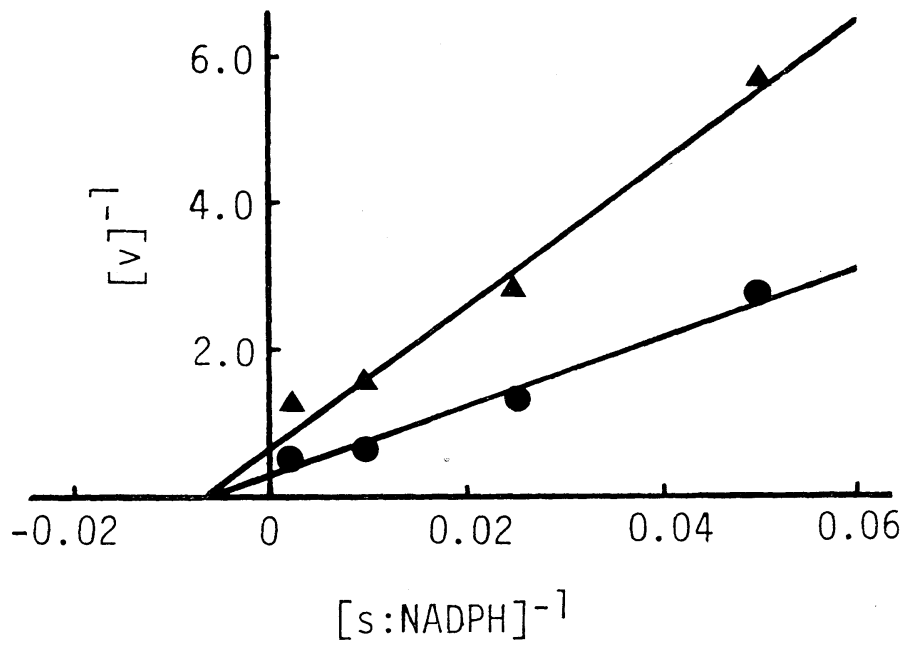

Fig. 4. Mode of inhibition by ketoconazole of rat testicular $17 \alpha$-hydroxylase for NADPH.

Microsome fraction containing $3.6 \mathrm{mg}$ protein/ flask was incubated with $10.6 \mu \mathrm{M}$ progesterone in the absence (O) or presence $(\mathbf{\Delta})$ of $31.3 \mu \mathrm{M}$ ketoconazole. Details are described in the legend to Fig. 2. 

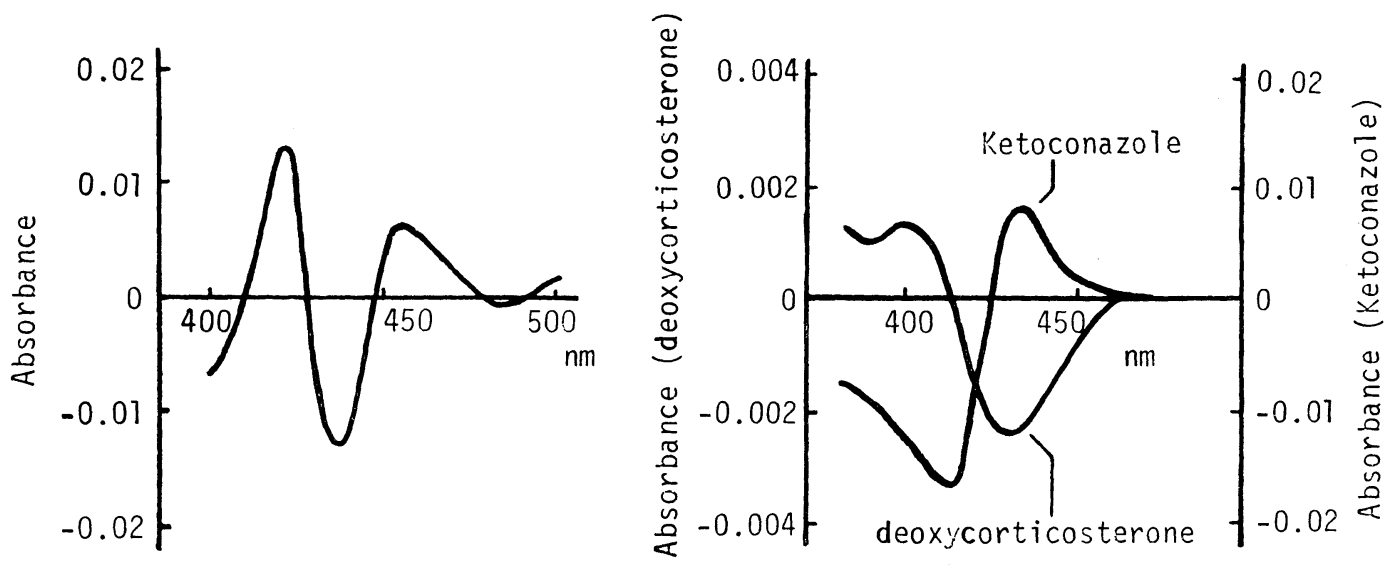

Fig. 5. The CO-binding spectrum of reduced cytochrome P-450 in the rat adrenal mitochondria (left panel) and substrate-induced difference spectra for rat adrenal mitochondrial cytochrome P-450 with $60 \mu \mathrm{M}$ ketoconazole and $18.2 \mu \mathrm{M}$ deoxycorticosterone (right panel).

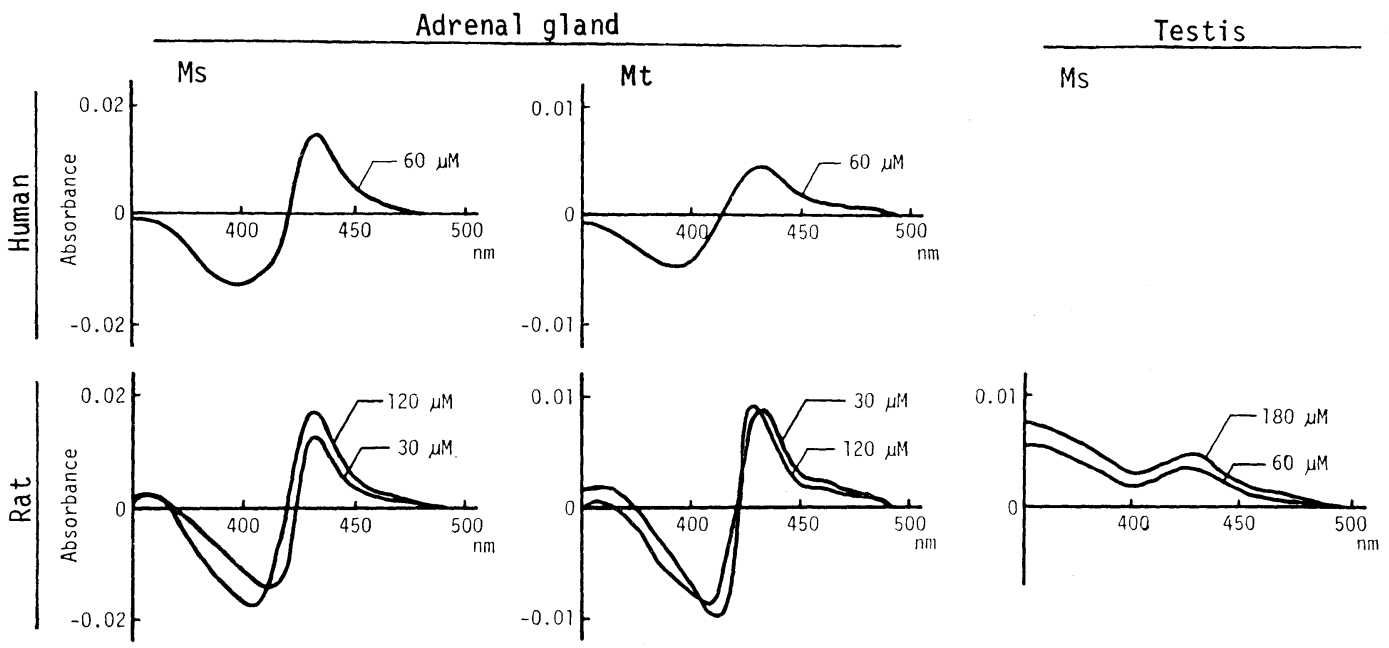

Fig. 6. Ketoconazole-induced difference spectra for cytochrome P-450 in adrenal glands and testes.

Ketoconazole concentrations are indicated in the figure. Total protein concentrations were as follows: $0.07 \mathrm{mg} / \mathrm{ml}$ for human adrenal $\mathrm{Ms}, 0.04 \mathrm{mg} / \mathrm{ml}$ for human adrenal Mt, 0.61 $\mathrm{mg} / \mathrm{ml}$ for rat adrenal $\mathrm{Ms}, 0.39 \mathrm{mg} / \mathrm{ml}$ for adrenal $\mathrm{Mt}$ and $0.74 \mathrm{mg} / \mathrm{ml}$ for rat testicular Ms. $\mathrm{Ms}$; microsome fraction and $\mathrm{Mt}$; mitochondrial fraction.

cytochrome P-450 in rat mitochondrial fraction was obtained as shown in Fig. 5 (left panel). In contrast to type I substrateinduced difference spectra of cytochrome $\mathrm{P}-450$ in the same tissue preparation with deoxycorticosterone, ketoconazole induced type II spectrum characterized by a peak at $432 \mathrm{~nm}$ and a trough at $412 \mathrm{~nm}$ with zero crossing at $423 \mathrm{~nm}$ (Jefcoate, 1978) (Fig. 5, right panel). 

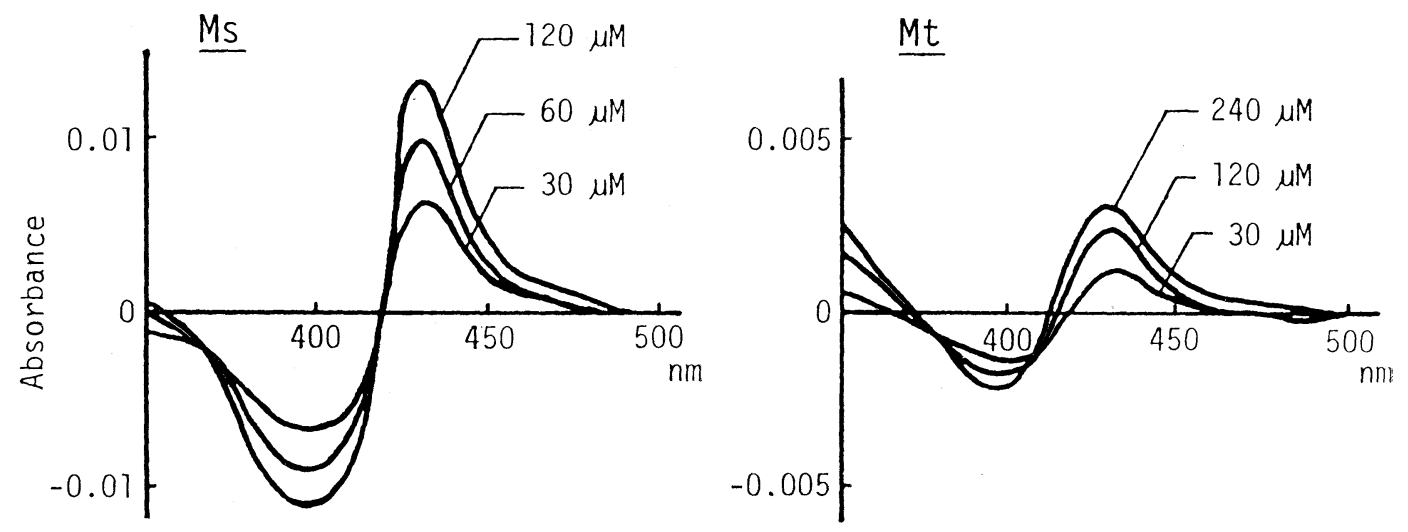

Fig. 7. Ketoconazole-induced difference spectra for cytochrome P-450 in rat liver.

Ketoconazole concentrations are indicated in the figure. Total protein concentrations are $0.77 \mathrm{mg} / \mathrm{ml}$ for $\mathrm{Ms}$ and $0.17 \mathrm{mg} / \mathrm{ml}$ for $\mathrm{Mt}$.

Comparison of ketoconazole-induced difference spectra of cytochrome P-450 in rat and human adrenal glands and rat testes

As shown in Fig. 6, cytochrome P-450 in all tissue preparations examined revealed type II spectral change due to the addition of ketoconazole. Though the difference spectrum of cytochrome P-450 in rat testicular microsome was rather obscure, the peak at $432 \mathrm{~nm}$ and the trough at $405 \mathrm{~nm}$ indicated a type II spectrum. We failed to show a binding difference spectrum of rat testicular mitochondrial cytochrome P-450 with ketoconazole. It may be due to the high turbidity and small amount of cytochrome $\mathrm{P}-450$ in the testicular preparation.

Substrate-induced difference spectra of cytochrome $P-450$ in rat liver

To investigate whether ketoconazole bound to liver cytochrome P-450 in a similar fashion to that mentioned above, spectral binding studies were performed using rat liver microsomal and mitochondrial fractions. As shown in Fig. 7, ketoconazole induced dose-related type II difference spectra to cytochrome P-450 in the rat liver.

\section{Discussion}

The present study shows that ketoconazole competitively inhibits the monooxygenase activities for steroid substrates in testes and adrenal glands of rats as well as human testes. Monooxygenases examined include $17 \alpha$-hydroxylase and C17-20 lyase in rat and human testes, $16 \alpha$-hydroxylase in human testes and 21-hydroxylase in rat adrenal glands. The findings are consistent with adrenal suppression during high dose administration of ketoconazole to humans (Tucker et al., 1985) and rats (Bhasin et al., 1986), in vitro inhibition of steroidogenesis in cultured mouse adrenal cortex tumor cells (Kowal, 1983), in vivo inhibition of testosterone production in male rats (Pont et al., $1982 \mathrm{~b}$; Trachtenberg, $1984 \mathrm{~b}$ ) and in men (Santen et al., 1983; Schurmeyer and Nieschlag, 1984). Further, ketoconazole has been reported to inhibit monooxygenases such as $17 \alpha$-hydroxylase and C17-20 lyase in the rat testis (Sikka et al., 1985) and also side-chain cleavage of cholesterol and $11 \beta$ hydroxylase in the rat adrenal gland (Loose et al., 1983). Ketoconazole has been also 
found to inhibit the hydroxylation of deoxycorticosterone at the $11 \beta$ and 18 -positions in reconstituted steroid monooxygenase systems (Nagai et al., 1986). On the other hand, ketoconazole has been reported not to inhibit rat testicular $17 \alpha$-hydroxylation of progesterone (Kan ei al., 1985). However, the substrate concentration used was too low to saturate the enzyme. Ki values of ketoconazole to monooxygenases for steroid substrates determined in the present study are definitely greater in rats than in men, while $\mathrm{Km}$ values of the enzymes to the corresponding steroid substrates are similar in both species. The results indicate that the affinity of ketoconazole with testicular monooxygenases examined is higher in men than in rats.

Since the enzymes mentioned above belong to the species of cytochrome P-450 dependent monooxygenases coupled with an electron transport system from NADPH, the component which binds ketoconazole is important in obtaining an insight into the mechanism of inhibiting effects of ketoconazole on monooxygenase and was therefore investigated in the present study. As a result, ketoconazole reveals no effect on the activity of cytochrome $c(\mathrm{P}-450)$ reductase purified from the rat testis and liver, the type II difference spectrum change of cytochrome P-450 and non-competitive inhibition of $17 \alpha$-hydroxylase activity for substrate NADPH in the rat testis. The former two findings indicate that ketoconazole binds to cytochrome P-450 and not to cytochrome $c(\mathrm{P}-450)$ reductase. The last finding of the non-competitive in hibition of $17 \alpha$-hydroxylase for NADPH can be explained as follows by assuming that ketoconazole binds only to the active site on cytochrome P-450 for steroid substrates. Since ketoconazole inhibits the same $17 \alpha$ hydroxylase for progesterone competitively, it occupies quantitatively the progesterone of fixed concentrations of both ketoconazole and progesterone, resulting in non-competi- tive inhibition of $17 \alpha$-hydroxylase for NADPH. Thus the results are consistent and indicate the binding of ketoconazole to the active site of $17 \alpha$-hydroxylase, in another words to cytochrome P-450.

Furthermore, the spectral analysis in the present study reveals that ketoconazole induces type II difference spectra not only in cytochrome $\mathbf{P}-450$ in microsome fractions of rat testes and adrenal glands of which monooxygenases are inhibited by ketoconazole competitively, but also in cytochrome $\mathrm{P}-450$ in mitochondrial fraction of rat adrenal glands and microsome and mitochondrial fractions of a human adrenocortical adenoma and rat livers. Steroid substrates induce type I spectral changes in testicular cytochrome P-450 (Nakajin et al., 1981) as observed in the present study using deoxycorticosterone. In contrast, the nitrogenous bases such as SU8000, SU10603 and metyrapone induce type II difference spectra and competitively inhibit $17 \alpha$-hydroxylase and C17-20 lyase activities on the cytochrome P-450 purified from neonatal porcine testis (Nakajin et al., 1981). Another imidazole agent, miconazole, also induce type II difference spectra in human placental aromatase (Mason et al., 1985). These facts also support the assumption of a direct interaction of a nitrogenous ligand of ketoconazole with the heme iron of cytochrome P-450 (Meredith et al., 1985).

The present results indicate that ketoconazole is a potent competitive inhibior of cytochrome P-450 dependent monooxygenases in the adrenal gland and testis examined and further binds to cytochrome P-450 universally. Ketoconazole is also a potent inhibitor of 25-hydroxyvitamin D 24-hydroxylase of cultured porcine kidney cells (Kan et al., 1985) and ergosterol biosynthesis in candida albicans as an antimycotic agent. The latter inhibition is attributable to interference with reactions involved in demethylation at $\mathrm{C} 14$ of lanosterol. The demethylation is also catalyzed by monooxygenases. 
Therefore, it appears most likely that ketoconazole is a universal inhibitor of cytochrome P-450 dependent monooxygenases. Adverse effects of ketoconazole on liver function can also be attributed at least in part to its inhibitory action on liver cytochrome P-450 dependent monooxygenases.

One of the reactions catalyzed in vivo by cytochrome P-450 dependent monooxygenases plays major roles in activation as well as inactivation of either mutagenic or tumor-promoting agents. Up to the present, however, it is not known whether carcinogenic and tumor-promoting agents might be activated or inactivated in the tissue of humans as a result of the inhibition of cytochrome P-450 dependent monooxygenases caused by the administration of ketoconazole. Therefore, great caution should be paid in prolonged administration of ketoconazole as a clinical therapeutic method including antiandrogenic therapy for prostatic cancer, even though recently such clinical trials have been carried out with favorable results (Trachtenberg, 1984 a ; Heyns et al., 1985).

\section{References}

Bachmann, E., D. W. Allmann and D. E. Green (1966). The membrane systems of the mitochondrion. I. The $\mathrm{S}$ fraction of the outer membrane of beef heart mitochondria. Arch. Biochem. Biophys. 115, 21-27.

Bhasin, S., S. Sikka, T. Fielder, U. Sod-Moriah, H. B. Levine, R. S. Swerdloff and J. Rajfer (1986). Hormonal effects of ketoconazole in vivo in the male rat: Mechanism of action. Endocrinology 118, 1229-1232.

De Felice, R., D. G. Johnson and J. N. Galgiani (1981). Gynecomastia with ketoconazole. Antimicrob. Agents Chemother. 19, 1073-1074.

Heyns, W., A. Drochmans, E. Van der Schueren and G. Verhoeven (1985). Endocrine effects of high-dose ketoconazole therapy in advanced prostatic cancer. Acta Endocrinol. 110, 276283.

Higashi, Y., J. Takahashi, K. Yoshida, S. J. Winters, H. Oshima and P. Troen (1984).
Seasonal changes in steroidogenesis in the testis of the rhesus monkey (Macaca Mulatta). $J$. Androl. 5, 70-79.

Jefcoate, C. R. (1978). Measurement of substrate and inhibitor binding to microsomal cytochrome P-450 by optical difference spectroscopy. Methods Enzymol. 52, 258-279.

Kan, P. B., M. A. Hirst and D. Feldman (1985). Inhibition of steroidogenic cytochrome P-450 enzymes in rat testis by ketoconazole and related imidazole anti-fungal drugs. J. Steroid Biochem. 23, 1023-1029.

Kowal, J. (1983). The effect of ketoconazole on steroidogenesis in cultured mouse adrenal cortex tumor cells. Endocrinology 112, 1541-1543.

Loose, D. S., P. B. Kan, M. A. Hirst, R. A. Marcus and D. Feldman (1983). Ketoconazole blocks adrenal steroidogenesis by inhibiting cytochrome P-450 dependent enzymes. J. Clin. Invest. 71, 1495-1499.

Lowry, O. H., N. J. Rosenbrough, A. N. Farr and R. Randall (1951). Protein measurement with the folin phenol reagent. J. Biol. Chem. 193, 265-275.

Mason, J. I., B. A. Murry, M. Olcott and J. J. Sheets (1985). Imidazole antimycotics: Inhibitors of steroid aromatase. Biochem. Pharmac. 34, 1087-1092.

Meredith, C. G., A. L. Maldonado and K. V. Speeg, Jr. (1985). The Effect of ketoconazole on hepatic oxidative drug metabolism in the rat in vivo and in vitro. Drug. Metab. Dispos. 13, 156-162.

Nagai, K., I. Miyamori, M. Ikeda, H. Koshida, R. Takeda, K. Suhara and M. Katagiri (1986). Effect of ketoconazole (an imidazole antimycotic agent) and other inhibitors of steroidogenesis on cytochrome $\mathbf{P 4 5 0}$-catalyzed reactions. J. Steroid Biochem. 24, 321-323.

Nakajin, S., P. F. Hall and M. Onoda (1981). Testicular microsomal cytochrome P-450 for C21 steroid side chain cleavage. J. Biol. Chem. 256, 6134-6139.

Nordlie, R. C. and W. J. Arion (1966). Glucose6-phosphatase. Methods Enzymol. 9, 619-625.

Omura, T. and R. Sato (1964). The carbon monoxide-binding pigment of liver microsomes. I. Evidence of its hemoprotein nature. J. Biol. Chem. 239, 2370-2378.

Omura, T. and S. Takesue (1970). A new method for simultaneous purification of cytochrome b5 and NADPH-cytochrome $c$ reductase from rat liver microsomes. J. Biochem. 67, 249-257. 
Oshimma, H., T. Sarada, K. Ochiai and B. Tamaoki (1967). Intracellular distribution and properties of steroid $16 \alpha$-hydroxylase in human testis. J: Clin. Endocrinol. Metab. 27, 2491245.

Pont, A., P. L. Williams, D. S. Loose, D. Feldman, R. E. Reitz, C. Bochra and D. A. Stevens (1982a). Ketoconazole blocks adrenal steroid synthesis. Ann. Intern. Med. 97, 370-372.

Pont, A., P. L. Williams, S. Azhar, R. E. Reitz, C. Bochra, E. R. Smith and D. A. Stevens (1982 b). Ketoconazole blocks testosterone synthesis. Arch. Intern. Med. 142, 2137-2140.

Santen, R. J., H. Van den Bossche, J. Symoens, J. Brugmans and R. DeCaster (1983). Site of action of low dose ketoconazole on androgen biosynthesis in men. J. Clin. Endocrinol. Metab. 57, 732-736.

Schurmeyer, Th. and E. Nieschlag (1982). Ketoconazole-induced drop in serum and saliva testosterone. Lancet. 2, 1098.

Schurmeyer, Th. and E. Nieschlag (1984). Effect of ketoconazole and other imidazole fungicides on testosterone biosynthesis. Acta Endocrinol. 105, 275-280.

Shikita, M. and B. Tamaoki (1965). Testosterone formation by subcellular particles of rat testes. Endocrinology 76, 563-569.
Sikka, S. C., R. S. Swerdloff and J. Reifer (1985). In vitro inhibition of testosterone biosynthesis by ketoconazole. Endocrinology 116, 1920-1925. Suzuki, K. and B. Tamaoki (1983). Acute decrease by human chorionic gonadotropin of the activity of preovulatory ovarian $17 \alpha$ hydroxylase and C17-C20 lyase is due to a decrease in microsomal cytochrome P-450 through de novo synthesis of ribonucleic acid and protein Endocrinology 113, 1985-1991.

Trachtenberg, J. (1984 a). Ketoconazole therapy in advanced protstatic cancer. J. Urol. 132, 61-63.

Trachtenberg, J. (1984 b.) The effects of ketoconazole on testosterone production and normal and malignant androgen dependent tissues of the adult rat. J. Urol. 132, 599-601.

Tucker, W. S. Jr., B. B. Snell, D. P. Island and C. R. Gregg (1985). Reversible adrenal insufficiency induced by ketoconazole. J. Am. Med. Assoc. 253, 2413-2414.

Van den Bossche, H., G. Willemsens, W. Cooks, F. Cornelissen, W. Lauwers and J. Custem (1980). In vitro and in vivo effects of the antimycotic drug ketoconazole on steroid synthesis. Antimicrob. Agents Chemother. 17, 922928 . 